\title{
Creation of resistant specimens of cotton (Tetranychus turkestani) using marker-based selection method in Uzbekistan
}

\author{
Mexriniso Umedova ${ }^{1, *}$ and Murod Rakhmankulov ${ }^{1}$ \\ ${ }^{1}$ Tashkent State Agrarian University, University str., 2, Tashkent province, Uzbekistan, 100140
}

\begin{abstract}
This article discusses the damage caused by pests to agricultural crops, including cotton, the importance of their control, the advantages of using modern biotechnological methods in the development of new pest-resistant varieties and foreign experience in this field, as well as preliminary research in this case was also briefly illuminated.
\end{abstract}

\section{Introduction}

The Government of the Republic of Uzbekistan has studied the requirements for cotton varieties on the ground to create new varieties of fast-ripening, high-yielding and highquality varieties, as well as varieties subject to water scarcity, soil salinity, high temperatures, heat, diseases and pests and resistant to various other extreme factors. Based on the new requirements, breeders are tasked with solving existing problems [1]. Worldwide cotton consumption is about 27 million tons per year. Uzbekistan is a leading producer and exporter of cotton [2, 4, 10].

From planting cotton to harvesting, many species of pests suffer from insects and diseases, as well as adverse natural conditions. In the early stages of cotton development, pests such as aphids, thrips, caterpillars and spiders cause damage, while in the later stages, various worm infestations lead to a decrease in cotton yield and fiber quality $[3,6]$. In India, \$ 660 million worth of pesticides are used annually on all agricultural crops, about half of which is used only for cotton. Solving such economic and social problems is one of the main tasks facing genetic, molecular-genetic, and selection scientists [5, 6, 9]. At present, many methods and approaches have been developed to create cotton varieties that are resistant to early ripening, biotic and abiotic factors, as well as high fiber quality and yield $[7,8]$.

Insect resistance of cotton depends on various morphological, biochemical and anatomical features. Morphological features of cotton, plant height, the length between the joints, the length of the petals, the width and thickness of the leaf surface, the density of hairs on the ventral surface and their length, such features are the main features of cotton. reduces the damage of sucking pests $[3,4]$.

\footnotetext{
*Corresponding author: mehrinisoumidova9185@gmail.com
} 
The most widely used types of markers in plant genetics and selection are morphological, biochemical (enzyme and protein) and molecular (DNA) markers. The number of morphological markers is limited and is often expressed in mature plants. Biochemical markers (isoenzymes) were introduced into plant genetics in the 1960s, but the number of these traits is also limited and rarely used today. Biochemical markers show the specific expression of tissues and can be influenced by environmental factors. In the last two decades, DNA-based markers (molecular markers) have become the dominant marker system for genetic analysis [9].

The use of new MAS-marker-based selection methods in the selection of insect-resistant genotypes is somewhat more effective than traditional long-term selection methods. In this method, the breeder is able to direct the desired gene to be included in a genotype, and as a result, in a short time will be able to create the desired variety, line, or primary source [6].

Scientists in many developed countries of the world conduct scientific research using the MAS method [5]. Scientists from the Dharwad Farm Agricultural University in India also conducted a study in 2012-2014 on the quarantine of Jassid (Amrasca beguttulla Isida), one of the pests of Gossypium hirsutum L. was studied the morphological, anatomical, molecular genetics and biochemical basis of resistance. In the study, hybridization between insect-resistant and non-insect-resistant specimens was performed on 0774-3-3 × 1-2-1, Raider $276 \times 8-1-2,0774-3-3 \times$ MCU-12, Raider 276 x MCU-13 combinations were obtained. In F2 and F3 generations, PCR screening was performed using about 200 SSR marker panels, showing polymorphism on 19 markers in parent samples of 4 combinations. The percentage of polymorphic markers was $9.5 \%$. Plants with the mark of resistance in the F2 generation of combinations were selected and studied in the F3 generations. Samples containing resistance marker loci were isolated from these hybrid combinations $[4,5,7]$.

Indeed, one of the most effective and environmentally safe ways to control pests is to create genetically resistant varieties. By introducing pest-resistant varieties into agriculture, we would not only be able to achieve economic efficiency by reducing pesticide consumption, but also reduce chemical pollution of the environment. In the marker-based selection laboratory of the Center for Genomics and Bioinformatics of the Academy of Sciences of the Republic of Uzbekistan, a number of studies are being conducted on the creation of cotton-resistant samples of sucking pests $[3,8]$.

\section{Materials and methods}

As for performing an analysis, 16 insect-resistant specimens in total were obtained from the PSUEAITI collection (Table 1).

Table 1. Varieties and specimens studied in the study

\begin{tabular}{|c|c|c|c|c|}
\hline$\#$ & Specimen name & $\begin{array}{c}\text { Catalog } \\
\text { number }\end{array}$ & $\begin{array}{c}\text { Botanical affiliation } \\
\text { of the specimen }\end{array}$ & $\begin{array}{c}\text { Origin of the } \\
\text { specimen }\end{array}$ \\
\hline 1 & C-8022 & 06785 & G.hirsutum & Uzbekistan \\
\hline 2 & Omad & 010316 & G.hirsutum & Uzbekistan \\
\hline 3 & Stoneville 2 B & 04231 & G.hirsutum & The U.S. \\
\hline 4 & C-4790 & 06773 & G.hirsutum & Uzbekistan \\
\hline 5 & Acala 3080 & 07230 & G.hirsutum & The U.S. \\
\hline 6 & New Impr & 07248 & G.hirsutum & South Africa \\
\hline 7 & Paymaster 111 & 07235 & G.hirsutum & The U.S. \\
\hline 8 & 289 A/43 & 07291 & G.hirsutum & Pakistan \\
\hline 9 & C-8266 & 07379 & G.hirsutum & Uzbekistan \\
\hline 10 & Type 4 g H3 g Montseral & 03440 & G.arbareum & India \\
\hline
\end{tabular}




\begin{tabular}{|l|c|c|c|c|}
\hline & Sea Island & & & \\
\hline 11 & Upland & 0681 & G.hirsutum & Armenia \\
\hline 12 & Ryad 285N6/108+109 & 03804 & G.barbadense & Turkmenistan \\
\hline 13 & Ryad 548 №6/33 & 03902 & G.barbadense & Turkmenistan \\
\hline 14 & Namangan-77 & 09751 & G.hirsutum & Uzbekistan \\
\hline 15 & C-1305 & 03674 & G.hirsutum & Russia \\
\hline 16 & Fibre Verte & 07223 & G.hirsutum & Algeria \\
\hline
\end{tabular}

The specimens were contaminated with Tetranychus Turkestani in an artificial environment, the resistance of the specimens to spiders was studied on a 5-point scale [2] and resistant specimens were isolated.

- 1 point - $5 \%$ of the leaf surface is damaged;

- 2 point - up to $25 \%$ of the leaf surface is damaged;

- 3 point - up to $50 \%$ of the leaf surface is damaged;

- 4 point - up to $75 \%$ of the leaf surface is damaged;

- 5 point - leaf surface is up to $100 \%$ damaged.

With Tetranychus Turkestani, young plants lag behind in growth, and during flowering they cause shedding of stems. Some types of cotton lose $50-60 \%$ of their yield in June, $25-$ $40 \%$ in July and 2-6\% in August.

Tetranychus turquoise matures in 15-20 days after laying eggs in spring and autumn, and in 8-10 days in summer. In one year, 15-18 generations of Tetranychus Turkestani grow up. Each female spider lays ' 00 and more eggs. This pest grows in nature at temperatures from $7.30 \mathrm{C}$ to $350 \mathrm{C}$, humidity $20-80 \%$. Development is high at a temperature of $25-300 \mathrm{C}$ and humidity of $46-65 \%$. Phenological observations show that the spider's exit from the winter coincides with the end of the first ten days of February, and the end of the development of the first generation coincides with the end of April. By the end of the season, giving birth to 17 generations, the development of the last generation will be completed in the second decade of October.

\section{Results and discussion}

Before infecting the leaves of plants with Tetranychus turkestani, observations were made (Figures 1 and 2).

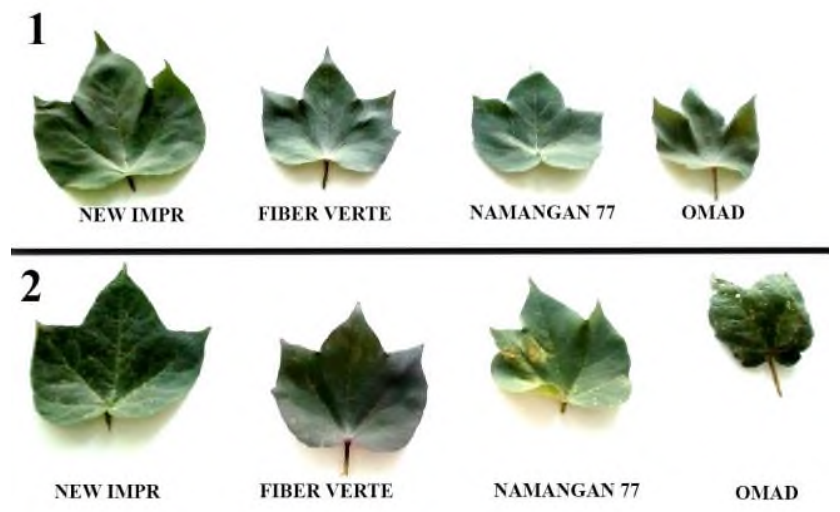

Fig. 1. Pre- and post-artificial appearance of the studied specimens with and without Tetranychus turkestani resistant to Tetranychus turkestani on the leaves: 1 - pre-infection appearance, 2 - post-infection appearance. 

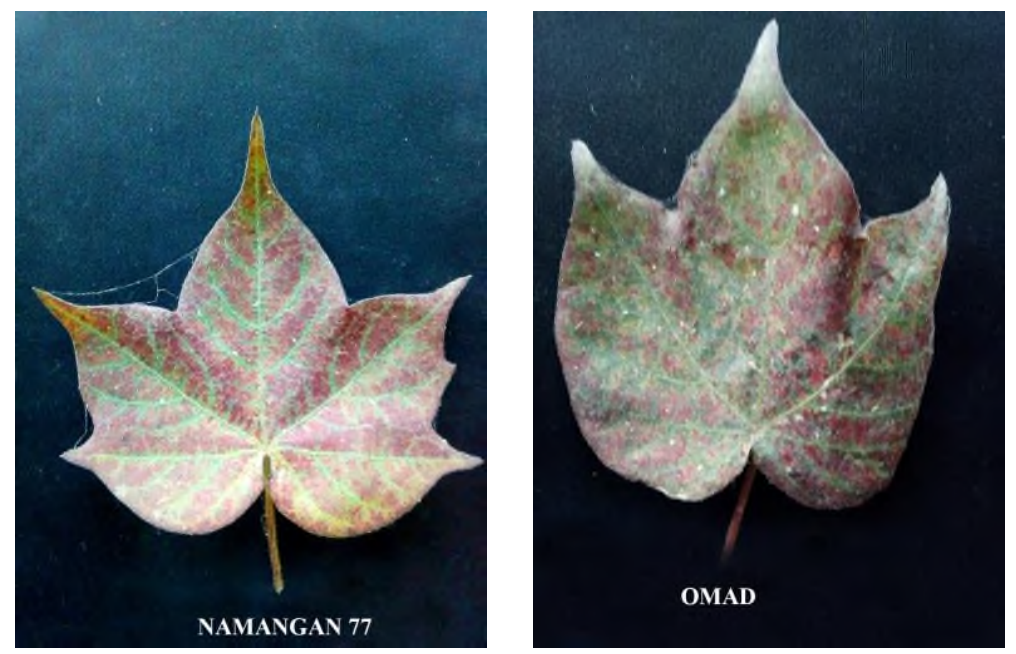

Fig. 2. Leaves of Namangan-77 and Omad varieties infected with Tetranychus turkestani

Table 2. Phenology of development of Tetranychus Turkestan (M.Babakhanova, A.U.Sagdullaev, G.Mirzayeva, M.Akmalova, S.Makhkamova)

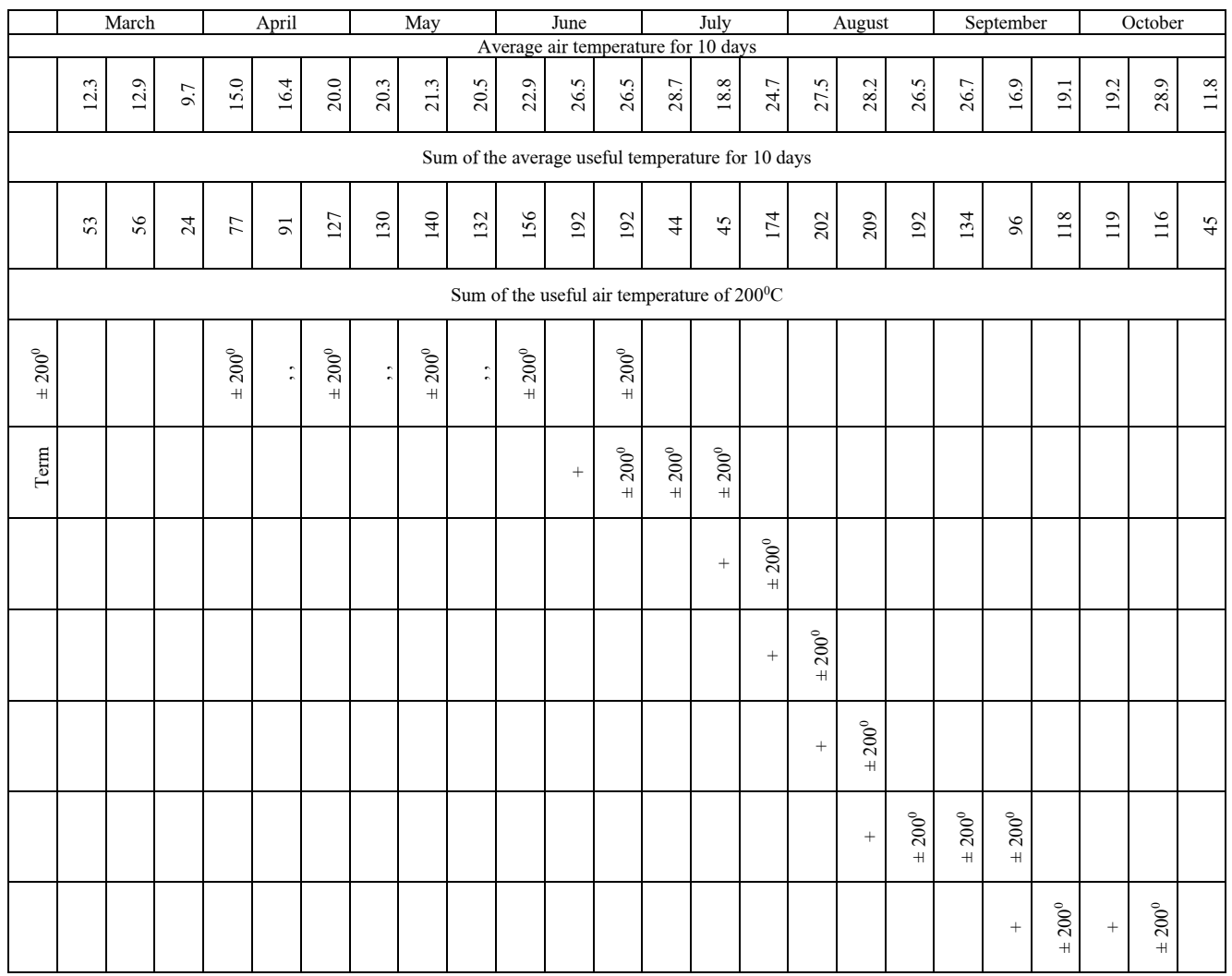

It is obvious that the multiplication of Tetranychus Turkestan depends on the favorable air temperature and the development period of forage plants. If the air temperature is above 
$18^{\circ} \mathrm{C}$, the canals will continue to grow, regardless of the age of the burrows in the crop. In autumn, when the temperature is below $18^{0}$, the red canals die. When the temperature of the canals during the feeding period is above $18^{\circ} \mathrm{C}$, it is difficult for them to prepare for winter, and they remain active as long as the crops are close to its lower developmental limit $\left(7.3^{\circ} \mathrm{C}\right)$ until they stop growing. The colors are green. The longer the Tetranychus Turkestani go to winter, the longer they will go out of winter. Depending on the early or late arrival of spring, this period can be moved forward or backward. When the predevelopment temperature is $7.3^{\circ} \mathrm{C}$, the total useful temperature of the ducts from the ovary to adulthood should be $200^{\circ} \mathrm{C}$. This, in turn, indicates the emergence of the next generation (Table 2).

The specimens were contaminated with Tetranychus Turkestani in an artificial environment, the resistance of the specimens to spider infestation was studied and plotted in Figure 3 below.

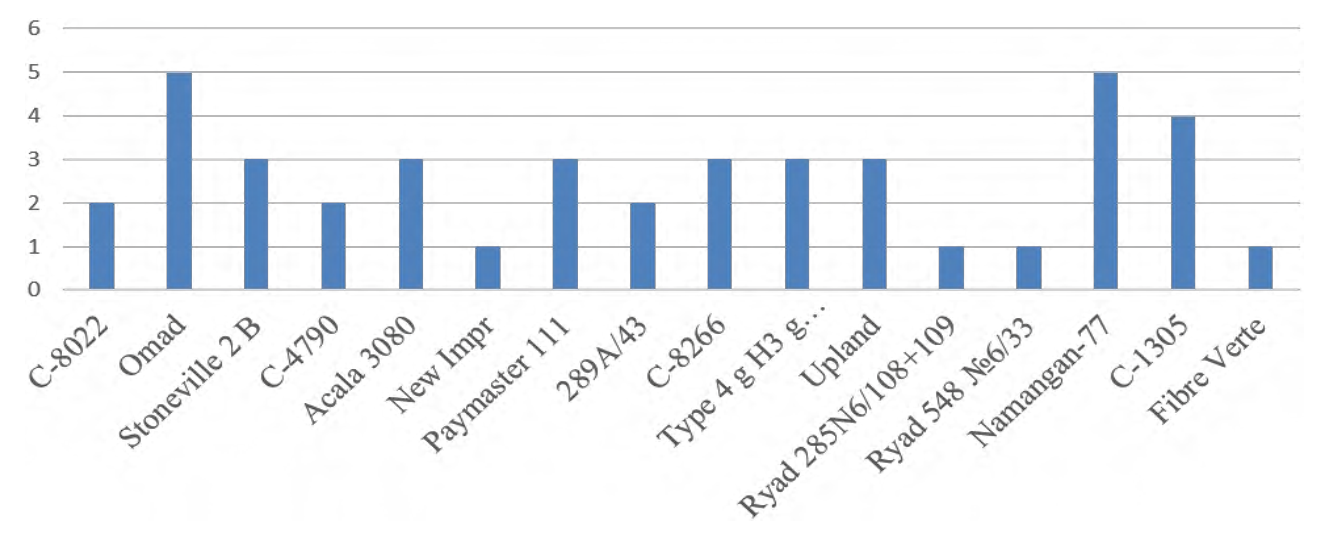

Fig. 3. Degree of spider infestation

In addition, the samples were studied and analyzed for value to several farms, in terms of fiber production, C-1305, Namangan-77, Omad, C-8022, Acala 3080, New impr, 289A/43 varieties showed high performance, while Fibre Verte, and Upland varieties showed high results, 23.4, with the lowest rates of $28.6 \%$ (Figure 4 ). 

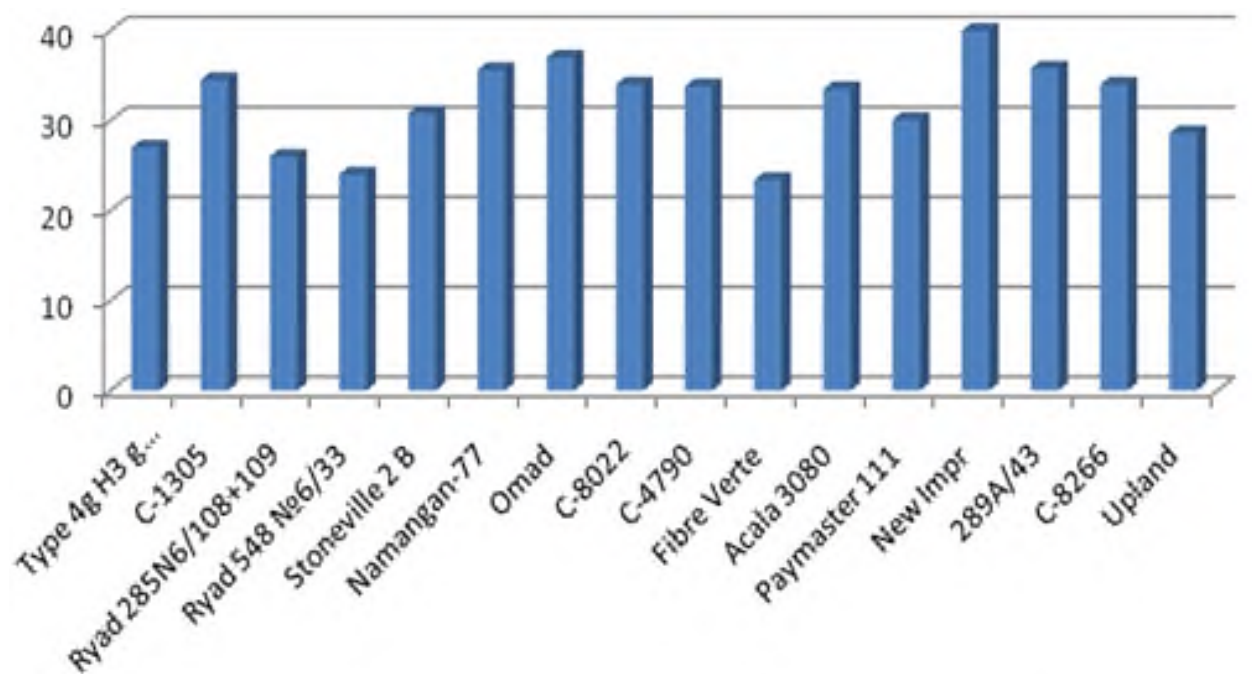

Fig. 4. Fiber production of cotton varieties, $\%$

Ryad 285 N/6108 + 109, Namangan-77, Omad, C-8022, New Impr varieties showed the best results in comparison with other samples (Figure 5).
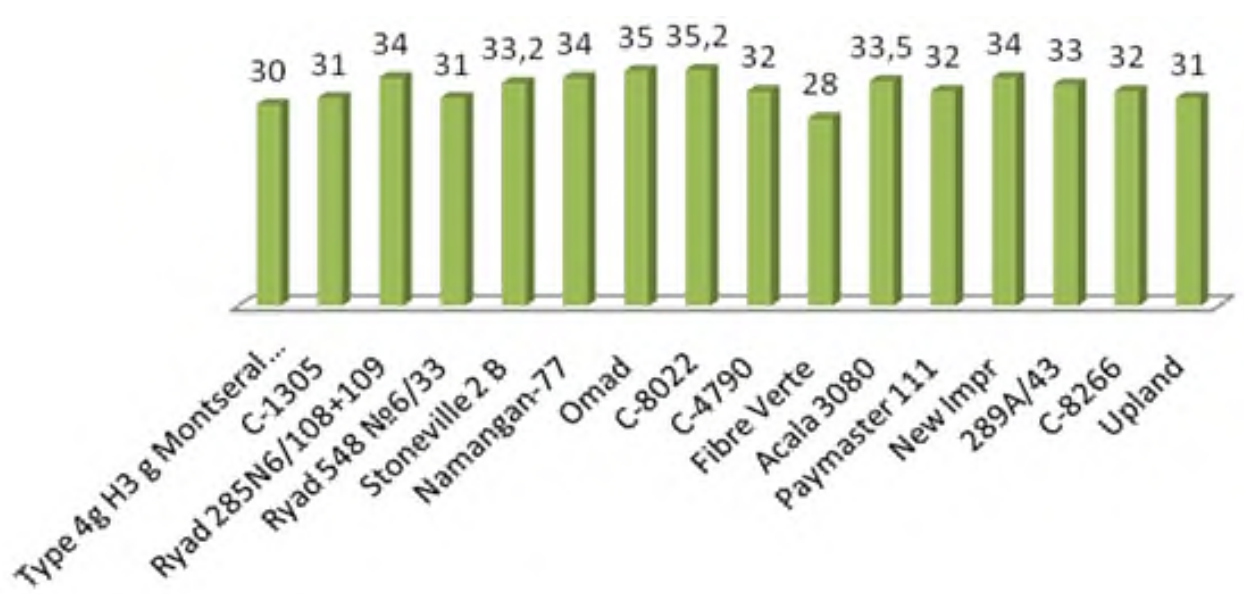

Fig. 5. Fiber length of cotton varieties, $\mathrm{mm}$

C-1305, Stoneville 2B, Namangan-77, Omad, C-8022, C-4790, Paymaster-111, $289 \mathrm{~A} / 43$ were examined for the weight of cotton in one cocoon. It differed from the others by the size of the stalks and the weight of the cotton in one cocoon (Figure 6). 


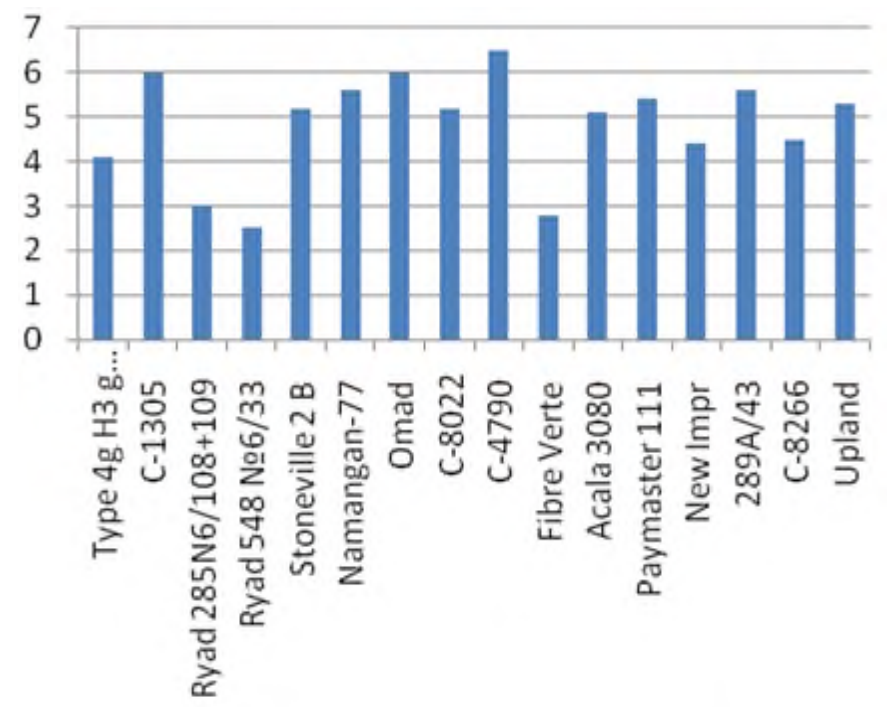

Fig. 6. Cotton weight per cocoon, $g$

Next, genome DNA was isolated from the samples and PCR was screened with SSR primers, and the degree of cross-polymorphism between the samples was studied by BNL3649 (Figure 7).

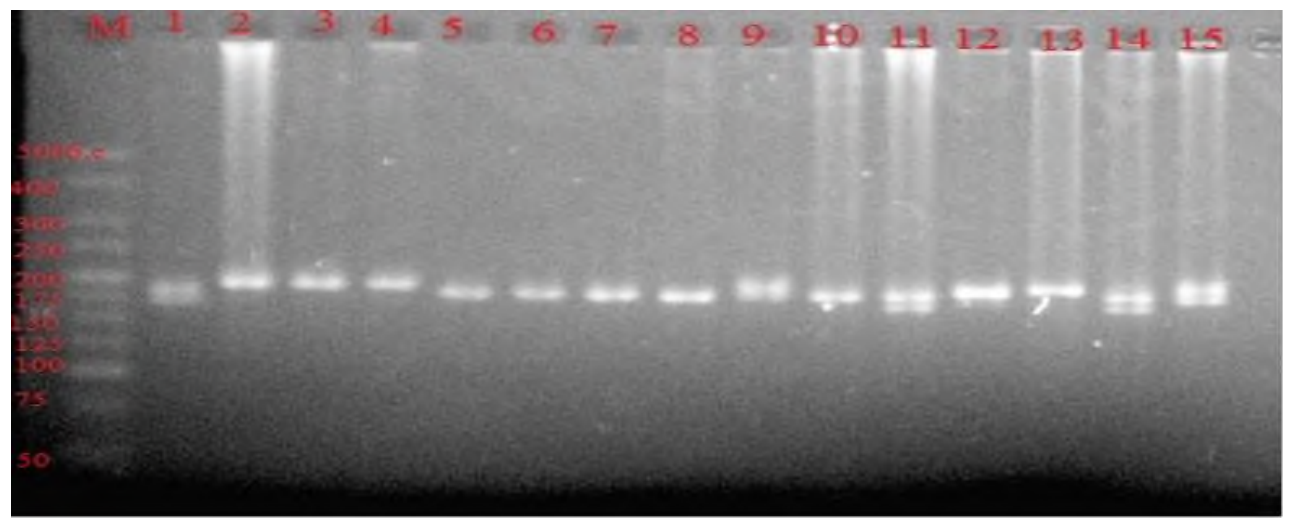

Fig. 7. M-marker and its molecular weight in 3.5\% agarose gel, the number of insectresistant samples 1-15 and their weight in gel by molecular weight

Transferring the Tetranychus Turkestani resistance mark to samples with high yield and fiber quality, resistant to sucking insects, using donor samples that have shown resistance to Tetranychus turkestani by analyzing the characteristics of the samples studied above. In order to do this, the following combinations were mixed and F1 generations were obtained (Figure 8).

\section{- Omad X Fibre Verte}


- Omad X New Impre

- Namangan-77 X Fibre Verte

- Namangan-77 X New Impr

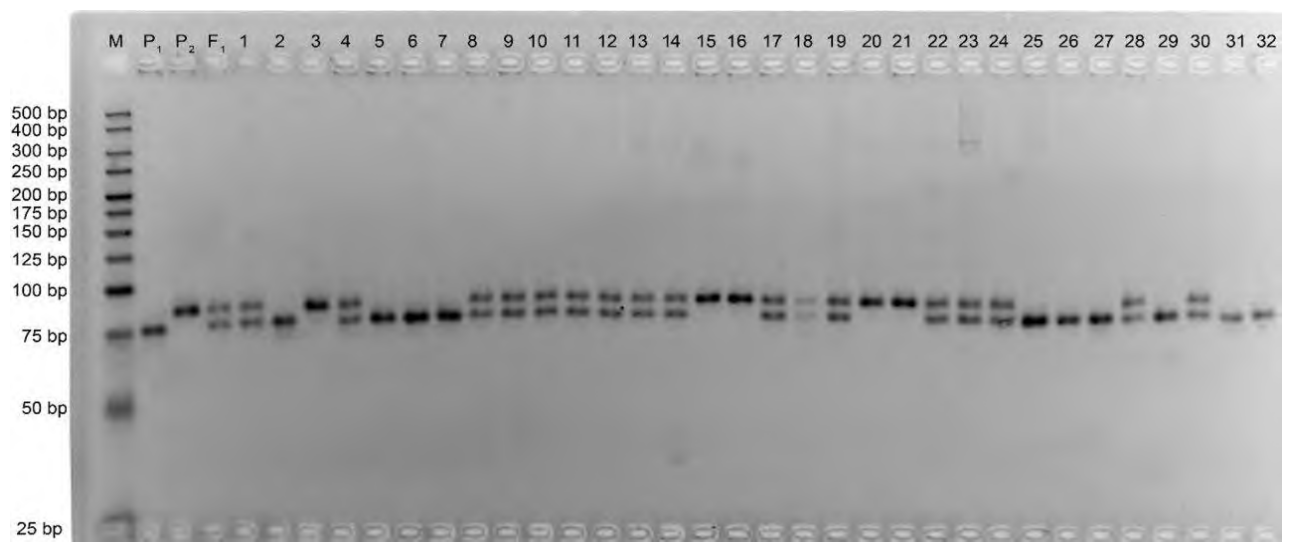

Fig. 8. M-marker and its molecular weight in 3.5\% agarose gel, P1-mother plant, P2-insectresistant sample parent plant, numbers of hybrids obtained from 1-32 and their molecular weight

\section{Concluion}

Namangan 77 and Omad varieties, which meet the requirements of production and showed high performance when analyzing the characteristics of the studied samples, such as fiber yield, fiber length, and weight of cotton in one piece, are not resistant to other samples studied by artificial spider mite It turned out that While it is known that the Fiber Verte variety, which exhibits high resistance to spiders, does not meet the production requirements in terms of fiber length, fiber yield, and weight per piece, New Impr has a low productivity index rindi.

In subsequent generations, leaf hybrids will be collected from these hybrids, genome DNA will be isolated, and PCR screening will be performed with appropriate DNA markers. The results are obtained by genotyping and selection of genotypes that show signs of resistance.

\section{References}

1. B. A. Khalmanov, A. Danabayev, M. E. Umedova, Bulletin of Agrarian Sciences 2(64), 13-17 (2016)

2. M. E. Umedova, N. N. Khusenov, A. A. Dulanazarov, SH. N. Juryev, O. S. Turyev, F. N. Kushanov, Proceedings of modern problems of genetics, genomics and biotechnology, 264-266 (2019)

3. M. E. Umedova, N. N. Khusenov, SH. N. Juryev, O. S. Turyev, Proceedings of modern problems of genetics, genomics and biotechnology, 262-263 (2019)

4. M. E. Umedova, N. N. Khusenov, O. S. Turaev, Bulleting of Agrarian Sciences 2(76), 78-83 (2019)

5. M. F. Awan, M. A. Abbas, A. Muzaffar, A. Alil, B. Tabassum, A. Q. Rao, I. Ahmad Nasir, T. Husnain, J. Agr. Sci. Tech. 17, 275-285 (2015) 
6. M. Sankeshwar, M. P. Jadhav, S. Adiger, R. S. Patil, I. S. Katageri, Indian J. Genet. 78(2), 252-260 (2018)

7. S. Isaev, I. Begmatov, G. Goziev, S. Khasanov, In IOP Conference Series: Materials Science and Engineering 883(1), 012080 (2020)

8. S. K. Isaev, R. U. Rakhmonov, S. S. Tadjiev, G. I. Goziev, S. Z. Khasanov, In IOP Conference Series: Earth and Environmental Science 614(1), 012147 (2020)

9. M. Rakhmankulov PalArch's Journal of Archaeology of Egypt, 17(6), 3140-3149 (2020)

10. R. A. Kulmatov, S. A. Adilov, S. Khasanov, In IOP Conference Series: Earth and Environmental Science 614(1), 012149 (2020) 